\title{
Love in Pre-Islamic poetry and Shijing
}

\author{
Xie Wei \\ Shijiazhuang, Hebei
}

BA, University of Virginia, 2016

A Thesis presented to the Graduate Faculty of the University of Virginia in Candidacy for the Master of Arts or Master of Science or Master of Fine Arts

Department of Middle Eastern \& South Asian Languages \& cultures

University of Virginia

May, 2016 


\subsection{Introduction}

1.1Both Arabic literature and Chinese literature owe their literary luxuriance to poetry. Ancient Arabs and ancient Chinese seem to have shared the same artistic penchant for using poetic composition as a way of voicing their inherent awareness of beauty, and in modern days both Arabs and Chinese are, with pride, calling themselves 'a nation of poetry' respectively, given the ample legacy of poetry they have been relying on to impel their ethos.

The earliest recorded Arabic poems are believed to trace back to the early decades of the sixth century A.D., which, though, may make no striking impression in its antiquity. However, we should consider the fact that back then the Arabic poetry had already demonstrated sophistication in both its form and content, and been enriched with conventions and even clichés, which should be a result of a long development over time. We should also keep in mind that Arabic poetry was entrusted with the tremendous and privileged momentum to flourish even before other art genres were known by Arabs. Until today, the Arabs would proudly look back to that era, with certain nostalgia, even though, as is indicated by the name Jāhilīyah, the age before Islam appears lawless: 'a society only loosely organized in tribes and with no established leader, a time in which tribe was pitted against tribe, the hand of all against all (Ilse Lichtenstadter, 1974,P5).' 'Living in the desert as nomads, the Arabs in the early days had no opportunity to develop the arts of architecture or painting. So they did not get an opportunity to develop decorative crafts, the aesthetic urge thus became concentrated in the art of poetry. (Krishna Chaitanya, 1983, P32)' it is the exclusive attention paid to poetry that lays the foundation for the unparalleled status of 
poetry in Arabic society. Indeed the Arabs have inherited from Pre-Islamic times an imposing body of robust poetry that has set the standard for successive centuries (Pierre Cachia, 2002, P2).

The ancient Arabic poetry (the Pre-Islamic period, roughly defined as 500-622 A.D.) that came down to us, as was collected in written form by early Muslim scholars (which is behind the composition of the poetry by centuries), was named qașìdah. In its most complete form, it consisted of several parts, usually three, which have to deal with certain topics, each subject to strict rules of imagery, expressions, and motifs of its own species. Those odes constructed on a particular tripartite pattern are 'best exemplified in seven- or, in a different collection, tenwidely recognized masterpieces known as Mu'allaqat, i.e. 'the suspended odes', so called because they were purportedly written in gold and suspended inside the $k a$ ' $b a$, the cubical shrine that was revered in Mecca even before it became the focus of the Muslim pilgrimage (Pierre Cachia, 2002, P4).'

The opening part, i.e. nasi b, consisting of the description of the abandoned encampment and of the poet's beloved mistress who once dwelled there; the rahill, which describes the poet's journey through the desert and his mount, the she camel, with comparisons of her to wild creatures, notably the oryx cow or bull, the onager, and the ostrich; and the final section which may be of several sorts - $f a k h r$, the poet's praise or boast of himself and his tribe, including the hunt, the feast, combat, the drinking scene, tribal wealth, authority, and generosity; or madīh, court panegyric in which the praise of the ruler takes the place of fakhr; or hijā', invective, which is, in effect, an inverted form of fakhr (Suzanne Pinckney Stetkevych, 1993, P4). ${ }^{1}$

\footnotetext{
${ }^{1}$ Even though Pre-Islamic poetry was immersed in a tribal setting where communal activities are involved, the poet intended to make that an external stimulus to which he would respond, thus distinguishing himself.
} 
On the other hand, approximately contemporary to the establishment of Islam, China, in the Far East, ushered in the Dynasty of Tang, which, for any Chinese with basic literature knowledge, would be automatically associated with poetry. Arriving at the zenith of Classical Poetry, Tang Dynasty delivered numerous poets and poems that would turn out to be unsurpassed for the coming generations. Nevertheless, what we are going to examine in the present paper is a monumental erected long before Tang Dynasty, the one without which such achievement in Tang Dynasty, a thousand years later, would be unattainable. Shijing, 'the Book of Songs' or literarily 'the Classic of Poetry', is impossible to be ignored, if one intents to reconstruct the integral history of Chinese literature. It is the first anthology of poetry in the entire Chinese history, collecting 305 poems dating back from the eleventh century B.C to the sixth century B.C. Shijing has set up an example for later men of letters with its ideology tradition and aesthetic awareness. Such influence was internalized as a temperament of Chinese poetry, as the coming poets show, in their style, rather that they loved and lived with the songs in Shijing, than that they merely read them and accept their influence.

A song in Shijing typically is a poem that deals with a single theme, and it tends to be concise and straightforward. These works were officially assorted in three sections in the book — Feng, $Y a$, and Song. It is commonly agreed that the Feng part is the most delightful one in its artistic achievement, even though the Feng section is believed to be composed, at least originally, by relatively unscholarly people, whereas $Y a$ and Song are works by men of letters. As is suggested by the name 'Feng', meaning wind or current, the poems under the subset are the ones directly reflecting real life and thus considered the most genuine ones as well. Feng covers various aspects of life led by ordinary people, such as courtship, marriage, battles, agriculture affairs, celebrations and so on. 
As the case with Arabic literature, poetry is the earliest literary form coming into being in

Chinese literature history as well, and it is also the earliest one to reach a considerably high level of maturity.

What I aim to do in the present paper is to constitute a comparison between Arabic Pre-Islamic (mainly from the Mu'allaqat) Poetry ${ }^{2}$ and The Book of Songs, i.e. Shijing ${ }^{3}$ (Even though there is a significant temporal gap between their estimated dates of composition.), primarily on the ground that they each represent the inception of the literature development in the two cultures and have been spiritually extended in later works.

Arabic Pre-Islamic Poetry and Shijing are both extensive in topic selection. However, I will focus on the expression of love from the two literary entities, for love is the universal eternal sentiment over endless generations, with its presence standing impervious to the elapsing of time the geographical barriers. Meanwhile, love does not remain monotony from a cross-culture point of view; love is moldable in one specific environment, and its essence is still universally recognized, because the societal and natural environments only superficially conduct the utterance of love that is underlyingly flowing in human's heart. Thus, the expression of love most directly mirrors the disposition of one nation subject to certain ideology, and even more significantly, it reveals the cultural qualities of one nation.

Apparently, love theme is not absent in Pre-Islamic poetry and Shijing. Shijing has been acclaimed for including lovely works about love, narrating the longing for love, the delight and

\footnotetext{
${ }^{2}$ We are going to select two of the Mu'allaqat as our sample to be analyzed (the representation from the Arabic part), namely, Labīd's Mu'allaqah and Imru' al-Qays' Mu'allaqah. In addition to that, I also include al-Shanfarā's poem, the one in the Mufaḍdaliyyāt, as an extension to our comparison.

${ }^{3}$ What those poems built was the eternal sentiment that spread over time imperishably, being intrinsic to human nature. Its beauty and its artistic mood surpass the other two sections. For that reason, this paper will exclusively shed light on the aesthetic atmosphere engendered in Feng.
} 
inflict by love. As with regard to Arabic Pre-Islamic poetry, love is almost a conventionally obligatory element composing one qașìdah, which is manifested in the nasīb part, an amatory prelude. However, those Pre-Islamic poets and those who contributed in producing the songs in Shijing converged significantly on the perception of love. We should be aware of the fact that $n a s i \bar{b}$ was exclusively concerned with a love affair that is no longer alive, whereas the love created in Shijing comes with a bright prospect.

1.2 Pre-Islamic poetry, withstanding and even enhanced by the constantly changing human society and the ruthless nature, is inclined to have a personal perspective to discover the internalized power. The Arabic word for 'poetry' is ši'r, and it triple-consonant root is š-'-r has a basic meaning that is concerned with 'feeling'. Such fact may prompt us to suppose that an Arabs would regard poetry to be much in the personal domain, since only individual emotions best annotate the connotation of 'feeling'. Thus Pre-Islamic poetry is a personal statement, concerning the poet's individual development. It is crucial for the reader to have a specific and distinct image of 'I' emerge in his mind while trying to understand Pre-Islamic poetry.

Love, as is presented in nasīb, should be metaphorically construed as a transition point in a broader view of the poet's life. Through the poet's own perspective, the love, lost and irretrievable, is examined. The poet re-experience his once-so-intense love and the pain caused by the loss of it in his recalling of the past, in order to demonstrate the imprint of love - that shapes the presence of him and leads him where he stands. By that sense, love is disruptive and inspirational. Love engenders the power that brings about the fierce upheaval, and for the poet, experiencing love is a dangerous and yet significant transition.

The poet has presented love, which is doomed to wither, as being dark and heave to allude to his painful struggle for a transition and the fierce strength of love that propels him. 
The beloved in Pre-Islamic poetry, as an individual with her own agency, has the freedom to run counter to the poet like they finally do. They are less docile and less cooperative, as often being rendered to be the receiver of love that the poet would ultimately loses control of. On one hand, the women's agency is a lively manifestation of the dynamic and loose society that is in constant motion, and on the other hand, the women's agency is also in accordance with the molding power of love: it is through the collision between the poet and his beloved that he reaches the awareness of his new direction. The image of the beloved women should be situated and understood in relation to the ' $\mathrm{I}$ '.

Contrary to that, the Chinese ancestors have long settled down. Shijing, of China, derived its essence from the urbanized city life in which members of the society behave as is coded by his position in the huge mechanism. Shijing itself is a propaganda of public order and moral, and it is institutionalized as a tool of soothing the potential conflict. Shijing has adopted a voice of everyone, not trying to promote a specific protagonist with certain characteristics.

Therefore, the 'I' in Shijing is extensive and blurry, meaning that everyone could be the 'I', and the 'I' represents everyone.

As with those Chinese poem-composers, who came onto the literature stage much earlier than those of Pre-Islamic period did, they took on the responsibility of making poetic composition resonate to the mass and preferred to dive into the bright side of love. Their works encouraged people to plunge into love, to savor the lightness and selflessness status of being in love.

The beloved, either male or female, is generally a positive participant of a relationship in responding to his or her suitor, carrying the glory of love. 
Both Pre-Islamic poetry and Shijing have demonstrated characteristics in their form that conform to the tendency of their content. Pre-Islamic poetry is lengthy and exhaustive: it has a sense of narration by telling a story which extends over time and space; whereas Shijing is short and ambiguous: it paints a picture, fragmented and instantaneous.

Such characteristics are natural results of their historical context.

Before we dive into the long river of history, we may want to familiarize ourselves with the two languages that lay in the basis of the two glorious literature entities. Undoubtedly, poetry is primarily the product of language, and thus the linguistic properties have had great impact on the poetic composition.

\section{0 linguistic characteristics}

Chinese, especially Classical Chinese, is a highly isolating language that lacks grammatical agreement and declension, and thus lexical items are juxtaposed together as they are independent and unrelated to each other, and to paraphrase these items combined as a complete semantic structure requires a sense of imagination to fill in unspecified information that joins the items.

彼采葛。

$3^{\text {rd }}$ person pronoun pluck cloth-creeper sentence-ending particle

$\mathrm{OH}$, he is plucking cloth-creeper,

一日不见，

One day not see 
For a single day I have not seen him;

如三月兮。

Like three-month sentence-ending particle

It seems like three months!

None of gender, number, and tense is a prominent grammatical category in Classical Chinese, namely the $3^{\text {rd }}$ person pronoun, “彼' $b i$, that initiates and notionally permeates the song is unspecified in gender, which means that the reader would never even know if the song is about a man or a woman. Notably, the main verb, ‘见' jian, meaning 'to see', has neither its subject nor object emerging in the sentence. The semantic blanks are automatically completed by the linguistic intuition of Chinese speakers. Such ambiguity, when performed in love songs, serves as moderating the rivalry, as is often seen in Arabic poetry, between the two parties of love, and thus puts emphasis on the purity of love.

The 'I' in songs of Shijing is hidden and vague. Predetermined by the characteristic of the Chinese language, the 'I' is not even necessary to appear, or grammatically indicated by any form, in a sentence, even though understandably certain action or state would be attributed to 'I' by logic.

$\mathrm{OH}$, he is plucking cloth-creeper,

For a single day I have not seen him;

It seems like three months!

Oh, he is plucking southernwood, For a single day I have not seen him; 
It seems like three autumns!

Oh, he is plucking mugwort, For a single day I have not seen him;

It seems like three years!

In the original song in Chinese, there is not a single 'I' corresponding to the action of 'seeing', though logically it is 'I' that carries out the action of 'see' (the 'I' is present simply because the English translation requires that). Therefore, songs in Shijing call for a great deal of immersion for the audience to as to fulfill the semantic structure that is implicit.

\section{Shijing leaves the blank that everyone can fit in, and due to the 'blurred subjectivity',} Shijing virtually provides a frame for the reader, into which they project his or her own being that resonates with the songs. A typical song in Shijing is normally construed as rendering a circumstance and directing into it certain emotion which would seem reasonable by common sense, but it is not concerned about shaping a specific and outstanding protagonist, as is in a story-telling process. Actually, those songs in Shijing are replete with cliché stereotypes that one can find recurring in later works.

The 'I' does not have substantial content, as being a specific person. This is relevant to the fact that poetic composition is not associated with personal status, and instead it is a 'public service.' Lack of personal status from the perspective of the speaker, which sometimes we assume to be the original writer, partly constitutes Shijing's ambiguity, which in turn gives rise to the universality of the poem and consequently the audience can freely relate themselves to it. We may be able to attribute the lack of personal status to the fact that poetic composition belonged then to the field of communal work, where once a song was conceived and put into 
circulation it no longer had the imprint of the original writer. 'The great majority of these songs were written by unknown authors and their words had been freely tampered with by various singers who felt justified in making improvements of one kind or another. Thus, it should not be too hastily inferred that these so-called folk songs were the primitive voice of untutored commoners or the random attempts at song-making by men and women in the street (Chen ShouYi, 1961, p23)'

The lack of subjectivity of Shijing may have something to do, as well, with the absence of the concept of authorship in the time when those songs were made, as Stephen Owen states in The Making of Early Chinese Poetry:

The idea of "authorship" was a historical formation in China, as it was in Europe. Since it was a process of formation, "authorship" can mean many things; it must, however, involve a claim that the particular words belong to a specific person and are not merely one possible articulation of a general truth. The words must be presumed to have been composed with that intention, to belong to the person, and they must be repeatable usually in writing. Authorship, then, is more than a name attached to a book. We can see forms of Confucius's composition of the Chunqiu or philosophers who claimed possession of certain ideas that circulated in books to which their names were attached."

Reversely, we may argue that lack of the awareness of authorship can possibly lead to the songs being considered as communal property and collective work, and thus reflecting more of "common sense".

Quite different from the Chinese language, in which ambiguity and ellipsis were tolerated and even encouraged, the Arabic language intrinsically required a quality of exhaustiveness. The nature of Arabic predetermines its specificity, as each linguistic element is not an isolated island but rather it coordinates with one another and complements one another. Moreover, Arabic, as a typical synthesis language, has to specify overtly a semantic and syntactic role for each lexical 
item present in a sentence, and there is almost no space for ambiguity in construing a sentence from a semantic point of view.

Pre-Islamic poetry centered on the 'I' that represents the original author.

The 'I', as well as its grammatically related forms, is in no way ambiguous, and the 'I' has a tangible shape, and that helped create a strong perception of authorship by both the writers and the audience who listened to judge him. There were remembered and celebrated poets from the initial phase of Arabic poetry, to which the Chinese counterpart, by which I mean the much earlier Shijing, appeared to be in the exact opposite situation. As is mentioned above, writers of the songs in Shijing are almost completely unknown (actually not a single poet can be named in that era), which is an indicator that in the era of Shijing personal status was not associated with poetic composition. From the very beginning, Arabic audience knew that what was told in a poem was associated with a specific individual, whose skill in using the language to recount his memories is factored into the assessment of his personal status. The poem was after all someone else's story, and knowing that, the audience was possibly not supposed to resort to their empathy to appreciate the poem. The poem gives a picture that is afar and extraordinary, beyond the reach of 'ordinary people', but meanwhile specific and distinctive. On the other hand, it is exactly because of the seemingly unreachable distance that the audience was gravitated and aroused, and for that, the poet needed to make his own image visible to the audience, and make his own voice heard.

Are those black-boughed orchards still back there

In that stray round of our old place,

Mute witness to where 
My lovely lady lived?

After twenty years absence I stopped there.

Hardly recognized the place.

Black stones marked where the cauldron hung

And a trench traced the cristern.

I saluted the place.

Wished it well.

I'm tired of life's labor now.

At my age I assure you I'm weary.

I've watched the Fates at work.

They strick once, they strike no more.

They don't and it's dotage.

Man's true nature

Cannot stay hid

But be known.

Today I know.

Yesterday I recall.

The multiple and consecutive uses of the word ' $\mathrm{I}$ ', including its grammatically related forms, is an unsupported style in the songs of Shijing. In the rare cases where the word 'I' is present in songs of Shijing, it is seldom used as a subject. In the poem quoted above, ' $\mathrm{I}$ ' is the agent of several actions, I stopped, I recognized, I saluted, I've watched, I know and I recall, and those actions constitute the traces and clues of ' $I$ ', the image of which is overwhelmingly compelling in the poem's semantic layout. 
When we look at the historical environments in which the two literary entities came into being, we will find out the rationality that lies in their artistic orientations.

\subsection{Historical conditions}

Literature is the product of the real world and life, and literature expressions are inevitably influenced by social and natural realities surrounding the author. Based on that and to set up the context of my comparison, I will explore the historical origins and environments out of which the Arabic literature and Chinese literature grew respectively to find out the rationality that lies in their specialties (in their forms and contents) they reveal in the subsequent comparison.

3.1 Scholars in China seem to reach a consensus where they ascribe the origin of art to human embarking on laboring.

The celebrated modern Chinese writer, $\mathrm{Lu} \mathrm{Xun}^{4}$ said, in his article on the history of Chinese literature in general, that:

The primitive men who were our ancestors had no language at the start, but to work together, they had to exchange ideas, and so they gradually learned to make different sounds. If they did not know how to express their weariness when carrying logs, for instance, one of them might cry: "Ho-yo! Ho-yo!" and this was a kind of literary creation. If the others approved of it and took it up, the thing was "published." Once such sounds were recorded by means of symbols, you had literature; so the originator was a writer, a man of letters of the "Ho-yo school"... Even today we can find many folk-songs by illiterate poets and folk stories by illiterate novelists. These are all illiterate authors.

\footnotetext{
${ }^{4}$ Lu Xun (25 September 1881 - 19 October 1936), a leading figure of modern Chinese literature. Lu Xun was a short story writer, editor, translator, literary critic, essayist, and poet.
} 
In this regard, Feng Yuan-Chun, In his book A Short History of Classical Chinese literature, (1973, P10) has almost thought of art, especially poetry, to be an inexorable part of human's life as they took up labor and were consequently distinguished from other species, and he says:

To lighten the burden of their toil and express the joy of achievement, the ancient Chinese, like the first men in every country, created rhythmic sounds and language which became the earliest poetry; while, as the centuries went by, labour heightened their perceptive powers and their aesthetic sense developed.

The ancient Chinese book, called 'wuyue chunqiu' (literarily 'Spring and Autumn in Wu and Yue'), includes a song entitled 'Dange', 'the song of hunting', which is thought to be close to the most primitive form of songs:

断竹, 续竹; 飞土, 逐宍。(Literarily 'cut the bamboo, join the bamboo; raise the dust, chase the pig')

The song manages to caption a hunting scene in merely eight characters. Such conciseness was fixated, favored and passed down from generation to another. What we see in Shijing is exactly the brevity inherited from its forerunner, in addition to its 'considerable degree of verbal refinement and studied artistry (Chen Shou-Yi, 1961,P25)'.

Apart from its predecessor, as a great source for Shijing's artistic orientations, certainly, the era that created Shijing gave more spiritual qualities to it.

The Chinese civilization was rooted in agriculture. By virtue of the great river — the Yellow River, which runs through the northern part of China, ancient Chinese were endowed with exceptional advantages for developing agriculture, which would in turn prompt urbanization. Within the dozens of centuries before Christ, during which the songs in Shijing were believed to 
be composed, the Chinese people who mastered technique of agriculture settled down and enjoyed the exquisiteness of crafting and verbal arts.

From 1046 B.C. to 771 B.C., China was in its second dynasty — Zhou, when the slave-owning form was gradually replaced by the so-called feudalism. As the geographic extent of the Zhou Kingdom was greatly enlarged with the annexation of the eastern regions, numerous feudal states were established to keep the people in subordination, to protect the royal domains and capitals, and to reward the services of kinsmen and supporters of the new dynasties. To consolidate its governing and stabilize its political system, the Zhou Dynasty attempted to constitute an ideal social order where everyone would be subjected to certain code of conduct according to his social status, and thus everyone would be content and placid in his position and would ultimately obey the central government. To maintain the stabilized social structure is the primary task for the government, who would prefer the art forms to be fitting the public mood. Owing to the powerful and comprehensive social system, plenty of art genres were initiated and refined remarkably, and those art genres were meanwhile entrusted with political missions.

The so-called 'Rites and Music System' was an important device to stem social conflicts. Social status, as well as its corresponding behavioral norm, was regulated by the rites parts, and music was applied as an emollient medium among different social divisions where tension potentially existed. In such background, bred by the relatively high prosperity and the stability, the songs in Shijing began to come into being as an institutional tool to adjust the relation between different classes. Therefore, Shijing has adopted a more positive attitude as a general orientation of its content, to the extent of being educating. Songs were thought to be meaningful as they voice the people in general. Based on the effect that Shijing was intended to achieve, its value is associated with its extensiveness. Thus, Shijing greatly exploited the universality that lies in humanity 
and the common pursuit for beauty to let the audience find their own voice in the songs, and feel connected with each other.

We should also keep in mind that originally Chinese poetry, in the time of Shijing, did not exist independently of dancing and singing. ${ }^{5}$ Musicality remained essential to poetry for quite a long period, so calling the poems in Shijing 'songs' is indeed not a figurative appellation. In fact, it is based on the kind of music the songs were sung to that they were classified under different titles, namely Feng, Ya and Song.

Since poetic composition was then blended into a rather composite art form, the verbal style, as well as the structure, adopted in the process was necessarily restrained, thus to reach the harmony with singing and dancing that served as the vehicle of the poem. The fact that poetry was integrated into a form of performance would in effect obviate the tendency of the poetry being episode-oriented. Songs in Shijing are much less narrative than Pre-Islamic poems. Songs in Shijing embraced simplicity, devoid of extraordinary drama, and through that they presented and put emphasis on the most genuine and purest affection shared by the mass. Nevertheless, we should never conflate the simplicity with bluntness and roughness. Indeed, with

\footnotetext{
${ }^{5}$ Pre-Islamic Arabic poetry, though already singled out as an art genre of its own wholeness, was also in essence a form of performance, since its excellence was judged by the listeners rather than the readers. By that sense, musicality was, as that of Chinese poetry, to the core of Pre-Islamic poetry: the temple in articulating the words and undulating rhythm must have been a very important consideration (A History of Arabic Literature p32). Accumulating from long-term practice, in order to appeal to the audience, 'the Arab had at his disposal a variety of meters; each verse consisted of a number of feet with its rhythmic sequence of long, accented and short, unaccented, syllables. At the end of each verse appears a rhyme which is contained in the last syllable only; it is produced by the vowel-consonant-vowel sequence of the last syllable of each verse which remains identical throughout the whole length of the qașidah. The effect of this combination of meter and repeated thyme-syllable is striking and fascinates the Arab attended to the sound of his language; his intuitive understanding of the metonymies and his delight in the elegant style arouse him to enthusiasm and passion. It was thus in classical times, when poetry was the art of the Arabs, and it still affects him in this way today (Introduction to Classical Arabic Literature, P27).' Nevertheless, unlike the songs in Shijing, without the distraction from singing and dancing, Pre-Islamic poetry had its aesthetic values entirely hinged on the verbal output of the poet.
} 
the form being short, songs in Shijing hardly attempted to produce a sense of magnitude (such as the societal vicissitude), and those songs were loved for being winsome because of their concentration on describing a rather transitory and yet engaging feeling.

Shijing' form is short, and its content is untwisted. What was sung in those songs are positive calls for seeking the bright sides of life.

She threw a quince to me;

In requital I gave a bright girdle-gem.

No, not just as requital;

But meaning I would love her for ever.

She threw a tree-peach to me;

As requital I gave her a bright greenstone.

No, not just as requital,

But meaning I would love her for ever.

She threw a tree-plum to me;

In requital I gave her a bright jet-stone.

No, not just as requital,

But meaning I would love her for ever.

The song, called Mugua, meaning 'quince', dwelt on only one scene, where, assumedly, two beloved ones exchanging tokens of love to reflect the sweetness of the promise that 'I would love her forever'. The three chapters, each comprising of four lines, repeatedly recount the same event, but provides no more details of the 'story'. The event of exchanging tokens of love was meant to be free of any impurities that are irrelevant to love itself. Without plot twists involved, the song draws the audience into an immersive state of appreciating love. Moreover, the 'she' 
and ' $\mathrm{I}$ ' that appear in the song as the leading parts are not exclusive: everyone is the 'she' or the 'I'.

3.2When we turn our attention to the Arabian Peninsula, where the Pre-Islamic poetry was born, it may be fair to claim that before the advent of Islam, the word 'Arabs' was a cultural ethnicity defined only by the common language they spoke, and it was better to considered 'Arabs' as a geographical concept_— people who came from the Arabian Peninsula and its environs.

While the Chinese ancestors, in the era recorded by Shijing, were busy weaving their simple patterns of literary beauty, the land and people of the Arabian Peninsula were staying almost silent in historical narrations. 'Arabs did not produce any written accounts of their history until well after the seventh century. (Greg Fisher, 2011, P20)' Of course, the Arabian Peninsula, as the cradle of Arabic language and literature, was not desolate of civilization and stripped of people. Krishna Chaitanye says in A History of Arabic Literature (2011,P1), that

According to some Babylonian inscriptions, a kingdom, lying in the south-west of the peninsula, was believed to exist as far back as 2400 B.C., and another ancient inscription, dated back in 2300 B.C., indicates the existence of another kingdom in Yemen. However, those states, prosperous as they might have been, vanished without a tangible trace. Moreover, it would be arbitrary to link those states with what we know at present the 'Arabs.

Many evidences of the presence of Arabs are attributed to the Roman Empire, who belittled the 'Arabs' and relegated them to 'barbarians'. Indeed, similar to Goths, Franks and Vandals, the Arabs, living along the periphery of the Roman Empire, could not resist the majesty of the empire and be impervious to its influence. If we want to investigate the beginning of Arabs' history, we are incapable of isolating it as an independent entity. Besides the Romans, Sasanians also built their empire to the east of the peninsula, and they ruled over what are now Iran and 
Iraq. Through the long-lasting seesaw wars between the two great empires, the Arabian Peninsula served as the buffer zone, where the Arab tribes were drawn to one side as allies fighting against the other side. The tribal chieftains 'mobilized soldiers with the money given by the imperial power and fought on its side when wars broke out (Krishna Chaitanya, 1983, P3).' The two empires wrestling, on one hand, had significant impact on the formation of the Arabs as a unified and independent people, for to some extent, their awareness of being a culture group was weakened. Yet on the other hand, Arabs were not completely incorporated and assimilated into other civilizations as they played such an important role in mediating between the two empires, and thus they were able to preserve and develop their own ways of living, which would turn later into the qualities that defined the people.

The Arabian Peninsula was sensitively responding to the delicate situation outside, and inside, the Arab tribes were not entitled to an easy and comfortable life. Compared to the ancient Chinese who led a self-sufficient life, the inhabitants in the Arab peninsula were less fortunate in supporting themselves on their own. From the earliest time one can refer to of the peninsula, especially Yemen, the basis of its prosperity depended largely on the trade route that crossed it and sent the products from India to Egypt, and a new, more convenient route would always replace the old one, resulting in the decline of a civilization. The nomads in the north were facing fierce competition for the limited and sparse resources. No close-knit overall political organization was founded to, effectively and permanently, unify the Arabs. They were gathered in tribes by kinship ties, for they had the common ancestor whose name became the name of the tribe. Wars were frequent and imminent at any time, as was a recurring motif of Pre-Islamic poetry. The fights between Arab tribes might have been a direct internal factor that undermined the solidarity of Arabs. 
Albert Hourani, in his A History of The Arab Peoples, depicts a picture of Arabs in the Pre-

Islamic period:

The greater part of the Arabian peninsula was steppe or desert, with isolated oases having enough water for regular cultivation. The inhabitants spoke various dialects of Arabic and followed different ways of life. Some of them were nomads who pastured camels, sheep or goats by using the scanty water resources of the desert; these have traditionally been known as 'beduin'. Some were settled cultivators tending their grain or palm trees in the oases, or traders and craftsmen in small market towns; some combined more than one way of life. The balance between nomadic and sedentary peoples was precarious. Although they erer a minority of the population, it was the camel-nomads, mobile and carrying arms, who, together with merchants groups in the towns, dominated the cultivators and craftsmen. Their ethos of courage, hospitality, loyalty to family and pride of ancestry was also dominant, they were not controlled by a stable power of coercion, but were led by chiefs belonging to families around which there gathered more or less lasting groups of supporters, expressing their cohesion and loyalty in the idiom of common ancestry; such groups are usually called tribes.

Arabs took the desert as their stage, where they moved with tents and flocks seeking pastures that varied by season, and presented their living, loving and dying in personal and tribal feuds.

Possibly, from the very beginning of the Arabic poetry, which is also the beginning of the entire Arabic literature, personal motifs were given particularly ample room to be elaborated. Unlike ancient China who had a rigorous social system, with its members situated in spots orderly connected, the Arabs back then were facing a more 'effervescent' society, where individual power was greatly emphasized and praised. The vicissitude is a continuously ongoing factor that shapes Pre-Islamic poetry. It is true for the poetry of the period "hate and war are in the present and love is in the past tense" (Dalgleish 1973:98)

Thus, Pre-Islamic poetry was equipped with a much broader view than that of songs in Shijing. Perhaps short poems were not adequate for accommodating the magnitude that lay in the nature of the Pre-Islamic poetry. The oral tradition may also partly explain the impressive length of Arabic poetry, of which a qașīdah usually consisted of fifteen to eighty lines. Lengthy speech 
would allow a better organization of thoughts for the poet. Compared to songs in Shijing, thus, Pre-Islamic poetry was afforded of more leeway to accommodate individual's mentality within its freedom for alternation of emotions and scenes.

On the other hand, poetic composition in Arabian Peninsula was greatly associated with personal status. Poets enjoyed unparalleled esteem from the mass.

In Pre-Islamic times, Arab poets were even sublimated into having supernatural powers and deemed as oracles of the tribes. They gave advises regarding where to find new pastures and new water-sources and pointed out the suitable location for the tribes' tents. During the constant feuds among Arab tribes, the poet was entrusted with an important task. Pierre Cachia says in this regard that:

Each (poet) was believed to have a demon, and at least the satires he directed at an enemy had the character of a curse. When so engaged he might appear with half his hair anointed, one shoulder covered and the other bare, and only one foot shod, and he would point at the opposing tribe while delivering his verse.

According to Krishna Chaitanya in A History of Arabic Literature, Ibn Rashiq of Kairouan tells us about the status of the poet in tribal days as thus:

Whenever a poet emerged in an Arab tribe, the other tribes would come and congratulate it. Feasts would be prepared and the women would gather together, playing on lutes, as people do at weddings. For the poet was a defence to their honour, a protection for their good repute. He immortalized their deeds of glory and published their eternal fame. On three things, the tribes congratulated one another: the birth of a boy, the emergence of a poet in their midst, or the foaling of a mare."

Arabs made poetry an affair within personal domain to reflect their distinctive existence in relation to their communities and environments. Pre-Islamic Arabic poetry was overall a personal statement conveying the uniqueness of an individual. Often times, we are supposed to be informed of the akhbār of the poets before we could actually establish ties within the text and 
shed lights on its creation motives. In explaining the 'boldness' of Imru' al-Qays in his sexual expressions, Suzanne Pinckney Stetkevych says in The Mute Immortals Speak,

The most obvious place to begin is with Ibn Qutaybah's explicit placing of the composition of the Mu'allaqah in the midst of the poet's wayward youth, directly after his frolic with the virgins at Dārat Juljul. The significance of the disproportionately long and unsually explicit erotic nasīb will become clearer in this light.'

... The day I entered the howdah - 'uayza's howdah-

She saying, "Many be your woes! You force me down!"

And again, as the saddle-frame swayed beneath us both,

"You've hocked my camel, Imru'u-l-Qays. Dismount!"

I told her, "Travel on, with its nose-rein loosened,

And do not banish me from your oft-tasted fruit.

Many like you have I visited at night - a pregnant or nursing mother,

Distracting her from a one year-old bedecked with amulets.

If, behind her, he cried, she turned towards him

With half her body, the other half unturned beneath me."

And a day when, on a sand dune, she denied herself

To me with an oath from which was no evasion:

"O Fātima, go softly with some of this cocquettishness.

If adamant to cut me off, be seemly!

Is your delusion that my love for you is fatal,

And that whatever you command, my heart obeys?

If any trait of mine displease you,

Then slip my garments from your own - they will slip off!

If we solely look at the nasīb part of the qașidah, the length has been extraordinary for any song in Shijing. Imru' al-Qays contains five episodes of him having illicit love affair with women in 
his qașīdah. The part quoted contains two of them, in which the two women are called 'unayza and Fāțimah. Pre-Islamic Poetry provides successive scenes of vigor, in which the characters are embodied by their speech and actions.

\subsection{Love is perceived differently}

4.1 The love portrayed in Pre-Islamic poetry is fierce, disruptive and meanwhile inspirational (it inspires because of its intensity that hurts the poet when it departs). Its renewing power lies in the internal orientation of the poet's spiritual journey that expends over a much wider range of time and space: the poet's advancing on his way is realized through the re-experiencing of an irretrievable love.

Usually, the poet would set, in the very beginning of the qașidah, a somber and melancholy tone, and in order for that, they either directly expresses the sadness or draw support from what inside his vision that is of desolation and solitude. In such a somber and gloomy air (sometimes it is even solemn), love is exerting its power through the pain it imposes, and thus the people in love are urged to grow, to take on the journey, and to quest.

Halt, two friends, and we will weep

For the memory of one beloved

Effaced are the abodes, Brief encampments and long-settled ones; At Minā the wilderness has claimed Monut Ghawl and Mount Rijām. 
The torrent channels of Mount Rayyān,

Their tracings are laid bare,

Preserved as surely as inscriptions are

Preserved in rock,

Dung-darkened patches over which,

Since they were peopled, years elapsed,

Their profane months and sacred ones

Have passed away.

In the opening lines of Labīd's Mu'allqah, alongside with the encroachment of nature and the departure of the culture, the despaired image of the poet, comes into our view. Everything that is associated with human is easily erased and forgotten. In this regard, Suzanna Pinckney Stetkevych (1993, P18) comments:

The poet's desolation, thus projected on the ruins, is expressed in terms of a nature/culture dialectic - that is pursued through the twenty-one verses of the nasīb. What society, culture, had created - both temporary and permanent encampments - nature has erased; What was once settled, cultivated, is now grown wild. Essential to this dialectic is the ephemeral and transitory quality of all that is cultural or cultivated — that is, human - as opposed to the permanence and perpetuity of the nature.

Under such guidance that the poet directed us with, we are pre-informed that love inexorably yields to a much more significant and compelling strength. Love is doomed to fall at its climax, and when it is finally turns silent, only the scars, as the proof of the presence of love, remain for those who once cannot extricate themselves to pay tribute to. On reading the Pre-Islamic poetry, we have to admit that the separation from the beloved is indeed the result of the recurring migrations of the tribes, which is part of the vicissitude of a society. However, acknowledging the impact of the general social factor on love, the poet is not trying to deny the existence of love, because what is once had becomes the internalized part of his being. As is discussed above, 
love has been a molding power toward the poet, and the desolation he has been drowning in is what makes us believe in the existence and magnitude of love. Separation can be a vivid expression of love.

During the process where love is headed towards destruction, the perception of it is preferred by the Pre-Islamic poets to be presented in the most animalistic way. Thus in their recollections, the realization of love lies in the pleasure of passionate intercourse. Sexual intercourse denotes the highest level of 'happiness' generated in love experience.

Then we spent the night,

The tent above us as if ringed

In basil, wind-wafted

In the evening, dew moistened,

Basil from the lowland of Halyah,

Abloom and redolent;

From a clime untouched by drought.

(Al-Shanfarā' poem in Mufaḍdaliyyāt)

Before that scene, we have been situated by the poet, Al-Shanfarā, in a setting of loss, caused by the departure of the beloved, and soaked in obsessive sorrow. By the time we reach the lyrical erotic night scene of the two lovers, it is quite clear that it is at most an irretrievable memory, more likely an idyllic fantasy.

Those episodes of love in Pre-Islamic poetry are devoid of spiritual communication which denotes that the poet and his beloved reach a spiritual harmony, and instead they render the two participant of love as almost opposing forces, headstrong and cynical, which sparks the exciting power of love, during intercourse, to the maximum. 
Then many women like you, pregnant and nursing,

Have I visited by night,

And distracted from her amuleted

One-year-old.

When he cried from behind her, she turned

Her upper half toward him,

But the half that was beneath me

Did not budge.

Such blatancy could definitely stun the Chinese love songs we put here as an object of comparison. In light of the Pre-Islamic belief that sexual intercourse with a nursing mother is harmful to the nursling, she is endangering her children, born and unborn, as well as betraying her husband, the father, or pater putativus at least, of her nursling and unborn child. This, we can take, as a proof of the Pre-Islamic poetry estranged away from the domain of 'common sense'. It is the freedom endowed by the poem's being an individual embodiment that induces the 'non-educating' aspect of Pre-Islamic poetry.

6.2 In rare cases can we find songs in Shijing that deal with sexual encounters, where the action is virtually an expression of the love's rising up to a higher level, yet steady and gentle.

Out in the bushlands a creeper grows

The falling dew lies thick upon it. Clear brow well rounded. By chance I came across him, And he let me have my will. 
Out in the bushlands a creeper grows,

The falling dew lies heavy on it.

There was a man so lovely,

Well rounded his clear brow,

By chance I came upon him:

'Oh, Sir, to be with you is good.'

In this song, sexual encounter is an allusion to the freedom of pursuing love, which is valued, but the love is not aimless and wavering. The very last line — 'Oh, Sir, to be with you is good' amounts to a promise of determined love, which transcends the pleasure of intercourse and transforms it into a resolution. Promise is yet another aspect of love that is scarcely dealt with in Pre-Islamic poetry, undue but understandable.

Compared with the pervasive point of view, adopted in Pre-Islamic poetry, that places love in the mist of pessimism and impulsiveness, Chinese songs in Shijing praises love for its uplifting effect, or rather they attempt to discover the bright sides of love as an intrinsic feature of human, which stands impervious to social conditions. Thus, we barely find love confronted with social impediments, but love is simplified as the concerted will of two people that solely lays in the essence.

For Pre-Islamic poets, the sentiments of love is manifested in the two opposite ends of the spectrum denoting between the pleasure (the intercourse) and the despair (the departure). Love itself constitutes a sharp contrast as is perceived in those poems. Songs in Shijing attempt to draw on and mix from both the sweetness and bitterness of love and eventually have the latter blended into the former, creating the flavor of love, fresh and not poignant. 
'Fair, fair, ' cry the ospreys

On the island in the river.

Lovely is this noble lady,

Fit bride for our lord.

In patches grows the water mallow;

To left and right one must seek it.

Shy was this noble lady;

Day and night he sought her.

Sought her and could not get her;

Day and night he grieved.

Long thoughts, oh long unhappy thoughts,

Now on his back, now tossing on to his side.

In patches grows the water mallow;

To left and right one must gather it.

Shy is this noble lady;

With great zither and little we hearten her.

In patches grows the water mallow;

To left and right one must choose it.

Shy is this noble lady;

With gongs and drums we will gladden her.

(Arthur Waley's translation)

Confucius commented this song saying, "there is joy without wantonness and sorrow without self-injury." Even when the songs address the uneasiness brought forth by love, they try to boost one's belief in and yearning for love, rather than leave a burden on the reader's shoulder, because the setback one encounters on his or her way of pursuing love is the manifest of its lightness and exuberance. 


\subsection{The beloved pictured in the poetry}

5.1 As we have already known, Pre-Islamic poetry is concerned with an individual journey, and therefore the beloved should be contained in the mentality of the poet. Women's images presented in Pre-Islamic qașīdah should be accounted for in a broader context connected with the poet's struggle and in a symbolical fashion, which is decided by the tendency of the poet to express himself and the non-unitary construction of the poem (if we do admit that the several parts bounded in one qașīdah are logically connected). Usually, love and the loss of it are part of the formation of the poet's presence. Women in the Arabic poetry are individuals with their own will, less docile and less devoted to love than in Shijing. Such portrayal of the beloved ones in Arabic poetry is so universally applicable that it may cause skepticism that those stereotyped women are fictionally generated in accordance with the later entering into a much broader view beyond the realm of love, as far as rahīl and fakhr go. With that viewpoint adopted, women are probably not as a 'pure element' as in Shijing to be celebrated with the halo of love. In general, women in Arabic poetry are in motion, showing no hesitation in drifting away from the poet who is the leading part of the 'love story', and the latter, reminiscent of the beloved one's departure and the separation, finally comes to the being as he is in his journey. What is worth noticing is that women in Pre-Islamic poetry is depicted as the ones who receive love dedicated by the infatuated poet, and finally embark on ruthless departure. The imbalance in love seems to be the underlying factor that results in the poet's transition. The images of women in Arabic poetry, present due to conventionality on the surface, subject to the underlying conception of the motif over the entire qașidah as a whole. They are the opposite force to the poet, and the two forces 
interact to motivate a new direction. The women's drastic motion is also the description of the fast changing tribal life.

In labīd's Mu'allaqah, the woman that left him eventually prompted him to start his journey.

The Mu'allaqah of Labìd

What do you remember of Nawār

When she has gone far off,

And her bonds, both firm and frayed,

Are cut asunder?

A Murrite woman who alit in Fayd,

Then dwelled nearby the people of hijāz,

How then could you hope

To meet with her again?

On the eastward slopes of tayy's two mounts

She alighted, or on Muhajjir's mount,

Then a one peak contained her,

And its foothills,

Then in șuwā'iq if she headed toward the Yemen,

So that by now

She is most likely in its Wihäf al-Qahr,

Or in tilkhām.

This is the most eminent part depicting the beloved woman, with the name of Nawār, in Labīd's nasīb. In fact, Nawār comes on the stage rather late in the first part of the poem, and yet before that, the poet has directly set up the imposing atmosphere of women's departing. We are beforehand informed that the poet has suffered from a separation from his beloved one. 


\section{When they loaded up their gear...}

The poet gives a maximally brief description to Nawār where the beloved one is a roaming point without a physical shape or a moral status attached to her, because she is no longer within the visible range of the poet. The blurring of the beloved one is actually part of the poet's subjectivity: her existence is only valid and conceivable in the mind of the poet, to which we, as the reader, have no access. As is put by Suzanne Pinckney Stetkevych, 'where the eye fails, the mind's eye takes over': the poet presents his thought about Nawār, conjecturing where she might now be and knowing that there is no hope for them to reunite. Through the recollection of the poet, an indistinct and indeterminate trace of Nawār appears who crosses along mounts and finally merges into the background. When that occurs in the poet's mind, the bitter recalling ends, and what is followed up immediately is the beginning of his desert journey. Such arrangement in part logically conforms to the poet's resolution to cut the bonds of the beloved one.

Be generous to him who treats you well,

But only the cutting of bonds remains

When affection falters

And its foundation fails...

Indeed, the poet treats Nawār as being a symbol with linkage to the past. The only substantial proof of love is the pain caused by the separation that leads to the loss of it, but the pain is stale and unnecessary. Coming to knowing that, the poet is determined to get rid of the irretrievable bygone days, move forwards and face the anew. Thus, Nawār is not presented in the poem to 
crystalize a cherished memory of love for love's sake, but rather she is the passage through which the poet accomplishes his transition from the melancholy yearning of the one that departs to becoming the actor of the separation who takes his own departure. Nawār is eventually reduced into an undiscernible dot in the unmentioned past that the poet turns his back to.

When reading the Mu'allaqah of Imru' al-Qays, we are destined to be misled if we are not informed in advance of his persona of tragic and mythic proportions, as we have already known. An overriding image of the poet would be frequently evoked: our attempt to comprehend the poem is a process where we draw near to the poem himself along the path that he has covered. We are not allowed to paraphrase his words in his poem arbitrarily by projecting our own life experience in it, as the transparence of his poems, as well as any other Pre-Islamic poets' works, lies in the reconstruction of the poet himself as a real person.

Suzanne Pinckney Stitkevych concludes that 'the poem is structurally related to poems of blood vengeance. (1993, P258)' The picture of the women are definitely not permit to overshadow or even meet as an equal to the magnitude of the poet, and instead they constitute the passage to manhood, accession to power, and intensify the poet's status as a king, the son of a king. They are not presented, by Imru' al-Qays, as the 'other' side on a par with him, as we would understand that love, ideally, is an spiritual affair of two people impartially, but rather the women seem to be 'subordinated', responding quite positively to the nature calling of sexual desire, since none of them is able to resist the seduction of the poet. They are, of course, cherished memories of the poet, and yet somehow overlooked by the poet, since the poet stresses that he is the donner of love, and he is hurt because the unbalanced love affair. The poet is not trying to sublimate the women in his poem to pay respect to the power of love. As we can see, the women who had illicit relationships with the poet are markers in his achievement of 
manhood that actually empowered him to proceed his journey. Raymond Farrin noted in his Abundance from the desert: Classical Arabic Poetry (2011, P6)that through his recollection of the women who all finally ditched him, he embarked on a healing journey — 'he plunges into the past again, only to return to the present at the end, to a resolution to his crisis.'

Imru' al-Qays opens up his nasīb by calling for his companions to halt at the ruins where he weeps as the memory of one beloved is conjured up in his mind. He then goes on a mental journey to unfold his recollection of a series of erotic encounters. Those encounters, as Imru' alQays leisurely spread them out, were meant by the poet to declare to the world his exaltation over the ordinary, as if he is climbing the ladder that helps him reach the man zone. In this, the beloved's agency is a mirror of the poet's own manhood.

\author{
As was your wont before her \\ With Umm al-ḥuwaytith \\ And her neighbor at Mount Ma'sal \\ Umm al-Rabāb!
}

Probably in the purpose of flaunting, Imru' al-Qays throws to us two, at once, of his mistresses, Umm al-ḥuwaytith and Umm al-Rabāb, whose names suggest they are married women, presumably not to the poet. 'hardly cased of innocent infatuation they consist rather of fornication with adulteresses (Suzanne Pinckney Stitkevych, 1993, P262).' The naivety of the poet was then disabused: he is an 'experienced lover'. 


\section{Musk as redolent}

As the east breeze when it bears

The scent of clove.

The poet remembers his mistresses, in a sensual way, by her unforgettable scent, which is almost the sole clue of Umm al-hiuwaytith and Umm al-Rabāb. They are rather tenuous than solid, except for their real names, serving as a starting signal of the poet diving into his 'glorious' past in search for the proof against the hopeless infatuation in love. He gives us a dose of illicit eroticism, voluptuousness and seduction to counter the sanctioned sexuality of marriage.

And the day I entered the howdah

'Unayzah's howdah,

Then she said, woe to you! You'll make me

Go on foot.

She kept saying, when the high-sided saddle

Listed with our weight,

You have hocked my camel, O Imru' al-Qays,

So get down!

Keep going, I said to her.

Slacken his reins,

But don't drive me away from your

Twice-to-be-tasted fruit!

The poet, in presenting his yet another encounter with the woman called 'Unayzah, renders her with more blood and spirit to allow her to appear as a person, a rather obstinate one, other than 
being simply a sensory stimuli as the previous two. Nevertheless, hardly different from Umm alhuwaytith and Umm al-Rabāb, 'Unayzah marks another successful venture of the poet, and 'Unayzah's cursing him for making her go on foot is where the sexual excitement is augmented and exported - the poet seizes the woman, figuratively, when she is at the tip of the spear. According to Suzanne Pinckney Stetkevych, the poet's entering the woman's quarters already suggests 'in the Arabic context the success of the poet's sexual penetration. He then avoids describing his violation to her directly and with more details, but instead he gives a comical episode of seduction, which is presented in the form of dialogue. I propose that the seduction coincides with their sexual activity where the woman's false refusal to the poet's sexual appealing was after all foiled and debunked. Up to this point, the reader would be prompted to imagine the intercourse between the two as powerful collision with passion. Again, the woman's role is to provide a background against which the poet gains his outstanding status. As we can see, the woman's firm insistence is in the end engulfed and smoothed by the composure of the poet, who sounds to be at the helm of the relationship between the two.

And one day on a sand dune's back

She rebuffed me, And swore an oath never

To be broken. O Fāțimah, don't try me

With your teasing, [Or] if you have resolved to cut me off,

Then do it gently. Are you deluded about me because Your love is my slayer 


\section{And whatever you command my heart \\ It does? \\ If something of my character \\ Has hurt you, \\ Then pull my clothes away from yours, \\ They will slip off. \\ Your eyes do not shed tears \\ But to pierce \\ With your two shafts the pieces of \\ My slaughtered heart.}

When the poet proceeds to expatiate on Fāțimah, we are already accustomed with his fondness for temporary joy with women, and thus expect no great deal of seriousness out of his seemingly devoted heart that aches for the loss of his love. This time, Fātimah is initially depicted as the antithesis of the poet — she is sharp, determined whereas the poet is soft and lingering desperately. The poet manages to show us his bleeding heart by making us listen to his crying underneath, but he does not intend to let us know what is inside Fāțimah's heart and deprives her of the chance to declare her maturity: Fāțimah, it appears, has abandoned frivolity for seriousness. All that the poet can focus on is his sorrow at the moment, and indulging in his lack of seriousness, he is therefore unable to see through the true will of Fāțimah, whose seriousness is not a jest or simple coquetry.

As the poet's recollection goes even deeper and further, Fāțimah is abstracted, again, as a symbol of physical beauty, and her attraction probably lies partly in the illicit nature of the relation between her and the poet. Yet the poet finally fulfills his will with Fāțimah, as we would expect, 
and during the process, the poet completely harnesses her as if they are two forces with great disparity.

I led her forth from her tent,

Walking as she trailed

Over our tracks the train

Of her gown of figured silk.

Then, when we had crossed

The clan's enclosure

And made our way to a sandy hollow

Surrounded by long-winding dunes...

As the poet leads Fāțimah to where the poet has his way, as if she were completely conquered, the locale and the shifting suns outside the tribal enclosure convey and reaffirm the unstable and anti-societal nature of the sexual encounter.

His appreciation for women is likewise based on his sexual drive. The poet throughout his poem has equipped himself with a perspective as opposed to women, as a natural gender, which we would anticipate to behave in certain fixed manners, and thus the boundary between the two sexes are distinctive. What we will see in songs in Shijing is that much less emphasis is put on the differentiation between men and women.

The women are finally reduced into scattered dots, and those dots are connected to form a line that leads to the self-shaping of the poet. 
The series of women images are certainly under the arrangement in relation to the poet's progress, which is headed to his personal growth and his character's development. It is possible that Imru' al-Qays' intention is to reveal his personal struggle and his efforts to digest the reality in order to enrich our understanding with his experience.

At the end of nasīb, as the recollection of his happy memories ends, which denotes that Imru' alQays has enjoyed various women's companion, he is finally healed because 'he may logically expect another lady — even several — to take the beloved's place (P9 R).' Those women, who the poet once loved so intensively are apparently no longer concerning him, help him turn to a new page to get over his current obsession.

The Brigand Poet al-Shanfarā, is an unlikely poet of love according to James Montgomerry in his 'Vagaries of the Qaşīdah (1997, P52)'. Such conclusion takes account the notorious and savage poem Lāmiyyat al-'Arab, 'in which society and its tribal ethics are defied, in which are rejected all established norms of behavior as the poet aligns himself with the animal kingdom and ekes out a precarious existence in the desert (James Montgomerry, 1997, P52).' Setting alShanfarā apart from his peers, His poem in the Mufaḍlaliyyāt presents a celebrated vision of love, rarely rivalled for the tender-hearted sincerity of its nasīb. In that, he gives more direct and independent depiction of the beloved woman that is truly worth respecting, and he tries to keep her out of the vision of men coveting women and therefore she may stand as an individual on her own. That is exactly what differentiates al-Shanfarā from the 'bad boy' Imru' al-Qays, for the former employs more tenderness and soft phrases to build up a woman mainly for her own sake, at least on the surface level. 
Alas, Umm 'Amr has made up her mind and gone on her way;

She said no farewell to her neighbors when she turned her back [on us].

Umm 'Amr decision took us by surprise, and the necks of [her] camels threw their shadows down [on us before we knew what was happening].

I watched what she did that evening, that night and that morning;

but she brought matters to an end and went away and turned her back.

Alas, my heart for Umayma, after all my yearning for her;

Picture her, the light of my life, having passed swiftly away [from me].

Alas my neighbor - you are one who bears no blame for rouses dislike when [womenfolk] are mentioned.

[How much] she delighted me when she walked abroad,

not letting her veil fall nor being spoken of in disapproval.

In the night, after little sleep, she give the drink she received in the evening to her women neighbors,

at times when gifts are few.

She pitches her tent in a place where she escapes blame,

when other tents have been pitched in a place where there can be blame.

As she makes her way, it is as though [her eyes] search for something she has dropped on the ground;

And when she talks to you, she does not say much.

Umayma! Her gossiping does not put her husband to shame;

[and] when women are mentioned she is [considered] chaste and illustrious.

In the evening he returns to the delight of his eye, returning a happy man,not having had to ask where she has been spending her time.

Fine but imposing, she was well-proportioned - she was perfect;

If any person is of the jinn in beauty, it is she.

We passed the night as though the tent above us was enclosed with sweet basil that had been touched by the evening breeze and the dew.

Sweet basil from the valley of Halya, in full flower, sweetly scented, its surroundings not subject to drought. 
The entire nasīb dwells on the perfection of Umaymah, both moral and physical, but the latter is more hinted than directly touched upon. Her leaving has put the poet in great pain, who yearns for her, the woman who bears no blame but deserves all praises. However, as is pointed out by James Montgomery, 'The picture drawn of their relationship is perhaps contradictory', for the woman presumably is having an adulterous relationship with the poet, and yet her husband chooses to have faith in her regardless to the existing 'gossiping'. James Montgomery $(1997, \mathrm{P} 54)$ follows with a suggestion that 'we understand the poet to be the consort of these lines, in which case the nasīb depicts the loss experienced by a man when the woman decides that their marriage is at an end and leaves him'.

This woman, Umaymah, indeed is the leading part of these lines, and even surpasses the poet, who seems rather content with that as a figure in his own poem. The poet worships the beloved one and paints his picture accordingly (James Montgomery, 1997, P55). He is mostly willing to abase himself and highlight the woman with his strong devotion and admiration for her. Nevertheless, the 'love' between Umaymah and the poet appears not to be an undying, selffueling obsession, because Umaymah, existing on her own and appreciated not for her ability to arouse desire, is painted minimally as a mundane participant of love, and rather she is so ideally promoted as being paradisiacal. That has actually distracted us into thinking about the beloved one, beyond the domain of love, to be a utopian picture of tribal allegiance. Thus, the poet's abandonment by the beloved one is emblematic of his abandonment by the tribe.

When we put the nasīb in connection with what follows in the poem and thinking of it as tribal, conventional and conformist, we are to find that 'Umaymah represents (however disingenuously, perhas) the tribal and social ideals of chastity, fidelity, generosity and modesty. Upon her 
separation from him and his rejection by her, the poet in turn rejects the socity with she represents. His grief and despair lead him to a life of violence and danger, to the rejection of the ties of kith and kin and to a courting of death so intense that it becomes an insistent Death Wish (James Montgomery, 1997, P59).'

Eventually, we have to situate the image of the beloved one in a bigger picture with regard to the orientation of the poet. The 'love' is a byproduct of conventionality and the underlying design.

Women portrayed in Pre-Islamic poetry are dynamic, as opposed to static. They can be imagined to be fireworks, which the poet ignite and finally lose control of, the sky of the poet, for a short and yet memorable moment, is enlightened, but in the end, they fall elusive.

5.2 Songs in Shijing were not constructed on multiple and complicated layers, and the love songs centered on love, as it is, exclusively. Love is not attached to an underlying structure, so it appears pure and elevated. Songs in Shijing has allowed the beloved to break away from the dominance of the 'I' (there is no particular 'I' in Shijing), seeing that their existence is for their own sake. Always shining with the glory of love, the beloved in Shijing are sheer perfection in love's own name. The beloved and his or her suitor are making concerted effort to create an atmosphere of the love being 'light', and the identity of both of them are not important and emphasized: they are flattened in one dimension, but due to the compelling appeal of love, they seem lively and real. The image of the beloved tends to be flattened in a fragment, but owing to the genuineness of love captured in Shijing they appear real and

\section{Thick grow the rush leaves;}

Their white dew turns to frost.

\section{He whom I love}

Must be somewhere along this stream. 
I went up the river to look for him,

But the way was difficult and long.

I went down the stream to look for him,

And there in mid-water

Sure enough, it's he!

Close grow the rush leaves,

Their white dew not yet dry.

He whom I love

Is at the water's side.

Up stream I sought him;

But the way was difficult and steep.

Down stream I sought him,

And away in mid-water

There on a ledge, that's he!

Very fresh are the rush leaves;

The white dew still falls.

He whom I love

Us at the water's edge.

Up stream I followed him;

But the way was hard and long.

Down stream I followed him,

And away in mid-water

There on the shoals is he!

(Note in the original version of the song in Chinese, there appears no word indicating 'I', which is supplemented as necessary in English. In addition, the beloved one could be a woman as well 
since no reference to the beloved one is clear enough to allow us to draw a decisive conclusion with regard to the gender.)

The beloved is put in a shrine to be condescending over the ' $\mathrm{I}$ '. He, or she, strengthened by the power of love, may ignore the existence of the 'I', as a suitor and a follower, and thus has no overlapping traces with 'I' to create a 'story' like that in Pre-Islamic poetry. The beloved can be rather sacred and never touched upon by the implicated 'I'. Unlike the case in Pre-Islamic poetry, the beloved are the focus of the poem. In the poem quoted above, called jianjia, the beloved is a point to be tracked, similar to that in Labīd's Mu'allaqah, but the one in Shijing has got rid of the imagination of the poet as his or her spiritual sustenance: he or she is a reliable entity that would not vanish by 'my decision'. The beloved one in the Chinese song is to be pursued with resolution and the one in Labīd's Mu'allaqah is finally and deliberately lost, with desperation. There is always certain space and distance maintained between the beloved one and the suitor in Shijing to generate an impression of love being pure and noble, whereas the beloved one in Labīd's Mu'allaqah, for example, is once so close.

The beloved in Shijing are calm and unhurried, not in drastic motion like those in Pro-Islamic poetry. They are not involved in contradiction against the 'I', and rather they are positive participant in love.

There was a girl with us in our carriage

Whose face was like the mallow-flower.

As we swept along,

Oh, at her belt the bright girdle-gems!

That fair eldest Chiang

Was fair and fine indeed. 
There was a girl with us in the same carriage-line

Whose face was like the mallow blossom.

As we swept along,

How those girdle-stones jingled!

That lovely eldest Chiang,

All that was told of her is true.

The girl, in the poem above, is fixated in a static state, giving out her radiance that is eternal, unforgettable, even though the encounter with the poet is just fleeting. She fascinates the one, i.e. the 'I', in the same carriage with her, but she might not be aware of that. For this wonderful moment, all that matters is that she has the overwhelming beauty, which sublimates the girl and purifies her, sheltered her away from the animal instinct. The implicated 'I' is, again, downplayed as the one who receives the girl's radiance aside and appreciates that with ecstasy.

Offair girls the loveliest

Was to meet me at the corner of the Wall.

But she hides and will not show herself;

I scratch my head, pace up and down.

Offair girls the prettiest

Gave me a red flute.

The flush of that red flute

Is pleasure at the girl's beauty.

She has been in the pastures and brought

For me rush-wool

Very beautiful and rare.

It is not you that are beautiful; 
But you were given by a lovely girl.

The song above presents a girl with a lively character, which is brought about by her teasing 'me' - she 'hides and not show herself', and what is contrasted by that is the picture of 'me' being perplexed (not knowing where she is) — 'I scratch my head, pace up and down'. The beloved one is the bright color in the picture that adds to it the vitality. Her teasing does remind us of one of Imru' al-Qays' sexual encounter where the girl, named 'Unayzah, curses him for making him walk on foot. They both seem to display a hint of 'refusal' to man, but in rather reversed situation. 'Unayzah is, from the beginning, contained and checked by the manhood of the poet, whereas the pretty girl in Shijing is an unfettered bird, suddenly surprising us with the delight of love.

The song has emphasizes an aspect of love which is not dealt with in Pre-Islamic poetry: that is the agreement of two souls on a spiritual dimension.

\subsection{Conclusion}

The individual is eminent in the Jāhilīyah period. Pre-Islamic poetry, specifically qașīdah, is the narration about a distinct individual, which is exactly the poet himself. He intended to reveal the process of his obtaining 'maturity' through his poem. Therefore, love, as a conventionally obligatory theme in nasīb, should be construed metaphorically. Love is, for the poet, a transition point, joining his past and his future. The poet is eager to get rid of his obsolete past and go on with his quest for new importance, and yet he must struggle for the transition. Love, or the 
experiencing of it, is the disruptive and inspirational power that shapes the poet's presence and lead him to continue his journey.

Therefore, love is perceived by the poet to be heavy, dark and fierce, which conforms to the great power in love that molds the poet and expels him to advance.

The beloved may have been rendered as an equal individual with agency that reflects the dynamic society they are in, for they make their own decision to leave the poet, but they are not considered an equal party in love: they are the receiver of the love given by the infatuated poet. The women's agency is contained in the journey of the poet, as the symbol that marks the growth of the poet. In that sense, the women's agency is in accordance with the shaping power of love.

On the other hand, Shijing was bred in stable urban life, and it is the universal voice in humanity that yearns for the beautiful and the good. Shijing is situated in a public domain, full of common sense. It attempts to constitute a pure emotional frame that everyone can fit into to allow them to feel connected.

Love in Shijing is bright and light, and it is the object of praise. Shijing encourages people to love. Those who are in love are portrayed in harmony. 
Works sited

Stetkevych, Suzanne Pinckney. The Mute Immortals Speak. Cornell University Press. Ithaca and London. 1993.

Cachia, Pierre. Arabic Literature - an overview. Routledge Curzon Taylor \& Francis Group.

Oxon. 2002.

Montgomery, James E. The Vagaries of the Qașidah. E.J.W. GIBB MEMORIAL TRUST.

Britain. 1997.

Lichtenstadter, Ilse. Introduction to Classical Arabic Literature. Twayne Publishers, INC. New York, N.Y.

Versteegh, Kees. The Arabic Language. Edinburgh University Press. Edinburgh. 1997.

Barakat, Halim. The Arab World. University of California Press. Berkeley Los Angeles London. 1993.

Chaitanya, Krishna. A History of Arabic Literature. Manohar Publications. Manohar. 1983.

Farrin, Raymond. Abundance from the Desert. Syracuse University Press. New York. 2011.

Fisher, Greg. Rome and the Arabs Before the Rise of Islam. Oxford University Press. Oxford. 2011

Hourani, Albert. A History of the Arab Peoples. 
Xie 48 